\title{
Production and Characterization of Bio-oil from Bio-mass by Circulating Fluidized Bed Pyrolysis Reactor
}

\author{
A.T. M. K. Hasan, M. Mohiuddin, M. B. Ahmed, I. J. Poly, M. Asadullah and M. S. Rahman \\ Department of Applied Chemistry and Chemical Engineering, University of Rajshahi, \\ Rajshahi-6205, Bangladesh.
}

\begin{abstract}
The objective of the present work is to install a modified suitable and compatible reactor system for the efficient production of renewable liquid fuel (bio-oil) from agro-based bio-mass. This new type of reactor system contains a combustor connected with the upper end of the reactor chamber. The bottom end of the reactor is connected with the bottom part of the combustor by a stainless steel pipe through which hot sand is circulated by the force of air pump. Thus, effective heat transfer from the continuously circulated heated sand as well as efficient biomass conversion into the reactor can be obtained. In this work, jute stick and bagasse abundantly available in Bangladesh were pyrolyzed separately in a continuous feeding circulating fluidized bed reactor at around $500^{\circ} \mathrm{C}$ for bio-oil production. The total bio-oil yields from bagasse and jute stick were about $69.5 \mathrm{wt} \%$ and $68.2 \mathrm{wt} \%$ respectively, which are higher than the yields obtained from fixed bed pyrolysis reactor. The total yields of char contents were $19.4 \mathrm{wt} \%$ and $21.7 \mathrm{wt} \%$ after complete pyrolysis of bagasse and jute stick respectively, which are less than that of char yields obtained from fixed bed pyrolysis reactor. Physical and chemical analyses of bio-oils were carried out by conventional methods. The density, viscosity, $\mathrm{pH}$, acid value, water, lignin, solid and ash contents of bio-oils obtained from both jute stick and bagasse were found to be $1.1 \mathrm{~g} / \mathrm{cc}, 3.1 \mathrm{cp}, 4.1,126.3 \mathrm{mgKOH} / \mathrm{g}, 14.0 \mathrm{wt} \%, 2.5 \mathrm{wt} \%, 0.05 \mathrm{wt} \%, 0.03 \mathrm{wt} \%$, and $1.12 \mathrm{~g} / \mathrm{cc}, 3.2 \mathrm{cp}, 4.0,127.1$ $\mathrm{mgKOH} / \mathrm{g}, 13.0 \mathrm{wt} \%, 2.5 \mathrm{wt} \%, 0.015 \mathrm{wt} \%, 0.025 \mathrm{wt} \%$, respectively.
\end{abstract}

Key words: Renewable energy, Bio-mass, Bio-oil, Pyrolysis, Fluid bed circulating reactor

\section{Introduction}

Without any argument, it can be said that energy is the driving force for the development of world economy. To fulfill these demands, fossil fuels such as petroleum, natural gas and coal have been playing the major role of total need of world's energy. The burning of fossil fuels for different purposes such as industries, transportations etc. causes environmental threat due to the emission of green house gases (Houghton et al., 2001). The necessity of energy will be growing with integral consumption rate for the survival of both developed and developing world for infinity of time. So, it is time to think seriously regarding alternative energy.

To satisfy the growing energy need and to solve the environmental problems, the world trends are moving towards renewable energy production parallel to the fossil fuel energy. As the amount of world's carbon source is fixed and it remains constant through carbon-cycle by the formation of cellulosic plants and latter on by decomposition with soil and

\footnotetext{
* Corresponding author: E-mail: alishaabir@yahoo.com
}

then accumulation by plant. For their burnable properties, cellulosic materials have been using as solid fuel for heating purposes. And now-a-days, these cellulosic bio-mass is considered as the renewable energy source with the highest potential to contribute to the energy needs of modern society for both developed and developing economies world-wide as well as chemicals (McNelis et al., 2002 and McGowan, 2000). Moreover, energy from bio-mass based on short rotation forestry and other energy crops can contribute significantly towards the objectives of the Keyoto Agreement in reducing the green house gases emissions (IEA Bioenergy, 1998).

Since the oil crisis in the mid 1970s, considerable effort has been directed toward the development processes for producing liquid fuels from lignocellulosic biomass. For last several years, bio-mass (cellulose, hemicellulose and lignin containing agricultural residues, forestry products and city 
wastages) has been tested for energy production by different routes (such as combustion, gasification and pyrolysis) (Lang, 2001). The combustion method has been widely practiced where-ever economically justified and the product can only satisfy the boiler heating purpose directly or power production via a Rankine cycle or similar. Efficiencies are low at small capacities and fouling and emissions are problematic in many applications (Bridgwater, 2004). Gasification offers higher efficiencies at all scales of operation while on the verge of being fully commercial still requires demonstration at commercially attractive scales of operations. There are added incentives for production of liquid fuels and chemicals. The advantages of pyrolysis over combustion and gasification processes for bio-oil production from bio-mass are that this method offers a liquid oil, which can be stored and/or transported to provide a more versatile optimized system as well as can be used as an energy carrier and as a source of various kinds of chemicals (Bridgwater, 2004). Two classes of pyrolysis exist and differ by the heat transfer. One type is the slow heating rate pyrolysis, also referred to as carbonization, aimed at producing charcoal (Bionett, 2000) by Rotary retort furnace (Secowarwick, 2006) and Brazilian beehive kiln (Fao, 2006). Another type is the flash/fast pyrolysis where the sample heated at high heating rates, several hundreds degrees per minutes or suddenly exposed to a high temperature. Fast pyrolysis is a process in which organic materials are rapidly heated to $450-600{ }^{\circ} \mathrm{C}$ in absence of air. Under these conditions, organic vapours, permanent gases and charcoal are produced. The vapours are condensed to pyrolysis oil. Typically, 50 - 75 wt.\% of the feedstock is converted into pyrolysis oil. BTG's fast pyrolysis technology is based on intensive mixing of biomass particles and hot sand particles in a modified rotating cone reactor. Fast pyrolysis reactor design include: Bubbling Fluidized Bed (Scott et al., 1985; Robson 2001), Circulating Fluidized Bed (Graham et al.,1988), Transported Bed (Wagennar et al., 2000, 2001), Cyclonic reactor (Diebold and Scahill, 1988; Czernik et al.,1995) Ablative Pyrolysis (Peacocke and Bridgwater, 1996), Entrained Flow Reactor, and Rotating Cone (vortex) Pyrolysis Reactor (Bridgwater, 2003). The three most important features of these reactor systems are: prompt heat transfer from reactor to biomass (small particles are therefore necessary), followed by efficient char removal by means of a cyclone before rapid condensation of the vapours. All this is done in order to maximize the bio-oil production with it's quality and to reduce cracking.
In the 1990s, several fast pyrolysis technologies reached near-commercial status (Gust et al., 2003). Among them, six circulating fluidized bed plants have been constructed by Ensyn Technologies with the largest having a nominal capacity of 50 t/day operated for Red Arrow products Co., Inc. in Wisconsin. DynaMotive (Van Couver, Canada) have demonstrated the bubbling fluidized bed process at $10 \mathrm{t} /$ day of biomass and commissioned their first 100 t/day in July 2004 in Ontario. BTG (The Netherlands) operates a rotating cone reactor system at $5 \mathrm{t}$ /day and is scaling the plant up to 50 $\mathrm{t}$ /day in the Far East. Fortum had a $12 \mathrm{t}$ /day pilot plant oprating in Finland until the the end of 2003. The bio-oil is a mixture of about 200 types of major and minor organic compounds (Fagernas, 1995). As a fuel, it can be directly used in engine, turbine and furnace (Brown, 1996). Work to date gives strong encouragement to believe that a diesel engine can be easily modified to run on $95 \%$ crude pyrolysis oil with no deterioration in output or rating (Leech, 1997).

The agro-based bio-mass is usually produced at the rural areas where a large scale pyrolysis plants can be installed. Due to the decupling nature of the pyrolysis plant, the bio-oil based small scale power generation plant can be installed in the remote areas where the bio-oil can be supplied and this is one of the most important advantages of bio-mass pyrolysis for liquid oil production (Andrews and Patniak, 1996). The by-products of the pyrolysis plant are burnable gas and char, which can be burnt for pyrolysis reactor heating, thereby reducing the additional production cost for heating system. The geographic and climate conditions of Bangladesh are suitable for growing sugar cane and jute, thus producing huge amounts of bagasse (about 21 million metric tons) as by product and huge amount of jute stick as agricultural residues per year. Usually, these are mainly used as solid fuels for cooking purpose in the rural areas or in some cases little amounts are used as raw materials in the pulp-paper industries and a part of these agricultural by-products are used in unorganized sectors (Bangladesh, 2004). However, these agro-based bio-mass can be used for bio-oil production using a modern technology known as fast pyrolysis. The produced bio-oil can be used in various energy sectors as a liquid fuel, thus reducing foreign petroleum dependence. This concept motivated many researchers world-wide to develop an economic process through Pilot Plant installation, which can efficiently produce bio-oil from their own bio-mass resources is still very much limited. But no attempt has been found still now in the literature to produce bio-oil commer- 
cially in Bangladesh. Although some researchers in various institutions in our country are trying in the laboratory scale to produce bio-oil from bio-mass, due to many barriers such as technical, economical difficulties and perception, policy complexities, commercial level Pilot Plant is still far from reality (Mia and Banik, 2008; Islam et al., 2003)). To overcome these innovative challenges, more research and development are needed in the field of fast pyrolysis and bio-oil testing, up-gradation as well as distribution to develop large scale applications. Therefore, the objective of the present study in to install a suitable and compatible reactor system for the efficient production of bio-oil from agro-based biomass available in Bangladesh as well as the characterization and up-gradation of produced bio-oil for commercial application in different sectors as liquid energy.

For the production of bio-oil by pyrolysis method, the heart of the process is the reactor and research and development has focused on the reactor. The rest of the process consists of bio-mass reception, storage and upgrading of bio-oil to transport fuel. Upgrading of bio-oil to a conventional transport fuel requires full deoxygenation, which can be accomplished by two main routes, hydrotreating (Elliott and Baker, 1983; Bridgwater, 1966; Bridgwater, 1994) and catalytic vapour cracking (Williams and Horne, 1994; Bridgwater, 1991). However, a comprehensive survey of fast pyrolysis processes has been published that describes all the pyrolysis processes for liquid production that have been built and tested in the last 10-15 years (Bridgwater and Peacocke, 1999; Bridgwater et al., 2001). Some other pyrolysis processes (Bridgwater and Maniatis, 2004) and (Reith et al., 2008), laboratory scale fixed bed and fluidized bed reactors (Asadullah et al., 2007), two chamber ablation type reactor (Dobele et al., 2007), have also been applied for the production of bio-oil from bio-mass. Some recent publications are mentioned, which have investigated for the development of the fast pyrolysis reactor processes (Park et al., 2010; Boateng et al., 2010; XiFeng et al., 2009; Osama et al., 2009; Choi et al., 2009Khodier et al., 2009; Elliot et al., 2009;Ragavendra et al., Selhan, 2009; Xiao et al., 2009; Brown and Wright, 2008; Venderbosch and Prins, 2010; Laird et al., 2009; Brown et al., 2008; Putra et al., 2009). Our recent modified circulating fluidized bed pyrolysis reactor is shown in the Figure 1.

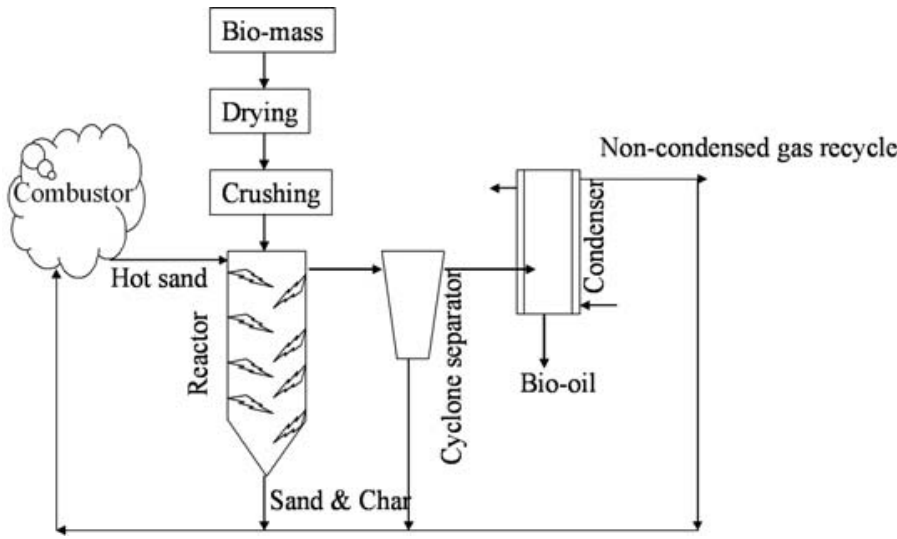

Fig. 1: Conceptual design of a circulating fluidized bed pyrolysis reactor

The reactor is made of stainless steel with the dimension of $50 \mathrm{~cm}$ height and $10 \mathrm{~cm}$ internal diameter. The reactor is connected with a combustor from where heating element (hot sand) is supplied followed by the bio-mass feeding into the reactor. The upper end of the reactor is connected with a cyclone in which produced gas and vapour can be separated from char. Cyclone is also connected with a condenser keeping into an ice bath. Chars from the reactor and from the cyclone and non-condensed gases from the condenser are recycled into the combustor for heating of sand.

\section{Materials and Methods}

\section{Raw Materials}

Various types of bio-mass including agricultural wastes, forestry products and city garbages are available being considered as some of potential sources of the main renewable energy, bio-oil. In our present work, bagasse obtained from the outlet of the sugar industries, jute stick collected from rural areas are used as raw materials of bio-mass for the production of bio-oil. These bio-mass usually contains more than $10 \%$ moisture, which are difficult to feed into the reactor as well as high moisture content bio-mass produce bio-oil with high water content resulted low efficiency of heating value. To avoid these difficulties, the feedstock was sun dried to reduce the moisture content less than $10 \%$ then crushed with a crushing machine to about $0.5-1.0 \mathrm{~mm}$ in particle size. Before feeding, the crushed materials were dried at $60^{\circ} \mathrm{C}$ keeping in the oven until constant weight.

Proximate and ultimate analyses (Asadullah et al., 2007) of bio-mass (Jute stick and Bagasse) were carried out previously 
Table I: Proximate and ultimate analyses of different biomasses

\begin{tabular}{|c|c|c|}
\hline \multirow{2}{*}{ Properties } & \multicolumn{2}{|c|}{ Values } \\
\hline & Jute stick & Bagasse \\
\hline Volatile fractions $(\mathrm{wt} \%)$ & $76-78$ & $68-70$ \\
\hline Fixed carbon $(w t \%)$ & $21-23$ & $27-29$ \\
\hline Ash content (wt $\%)$ & 0.62 & 1.26 \\
\hline $\mathrm{C}($ dry basis wt\%) & 49.79 & 48.58 \\
\hline $\mathrm{H}($ dry basis wt $\%)$ & 6.02 & 5.97 \\
\hline $\mathrm{O}($ dry basis wt $\%)$ & 41.37 & 38.94 \\
\hline $\mathrm{N}($ dry basis wt $\%)$ & 0.19 & 0.20 \\
\hline $\mathrm{Cl}$ (dry basis wt\%) & 0.05 & 0.05 \\
\hline $\mathrm{S}($ dry basis $\mathrm{wt} \%)$ & 0.05 & 0.05 \\
\hline
\end{tabular}

in our laboratory. The proximate analysis results based on TGA profile is shown in Table I as follows.

\section{Pyrolysis procedure}

Pyrolysis is a thermal decomposition of bio-mass occurring in the absence of oxygen. Lower process temperature and longer residence times favour the production of charcoal, high temperature and longer residence time increase the biomass conversion to gas and moderate temperature and short vapour residence time are optimum for producing bio-oil liquids. In the fast pyrolysis method, bio-mass decomposes thermally to generate mostly vapours and aerosols with some charcoal. After cooling and condensation, a dark brown mobile liquid is formed. The essential features of a fast pyrolysis process for producing liquids are: (i) very high heating and heat transfer rates at the reaction interface, which usually requires a finely ground bio-mass to give sufficiently small particles to ensure rapid reaction; (ii) carefully controlled pyrolysis reaction temperature of around $500{ }^{\circ} \mathrm{C}$ (iii) short vapour residence times of typically less than 2 seconds; (iv) rapid cooling of the pyrolysis vapours to give the bio-oil products; (v) dry feed to typically less than $10 \%$ moisture content in order to minimize the water in the product liquid oil; (vi) separation of solids char and collection of the liquid product (bio-oil).

First of all sand used as heat carrier contained in the combustor was heated by ring gas burner along with air passing. The ratio of air-gas was controlled by flow meter. When temperature of the sand in the combustor attained at around $500^{\circ} \mathrm{C}$, the hot sand was allowed to continuous passing through a visible glass tube into the reactor. At the same time bio-mass was feeding on the hot sand into the reactor. The flow rate of heat carrier hot sand and bio-mass was controlled by screw valves. The bio-mass feeder consisted of a conical hopper with a screw valve at the bottom, allowing continuous feeding by a motor driven screw shaft. The temperatures of the heat carrier hot sand in the combustor and of the reactor were observed by using thermocouples. The total pyrolysis system of the reactor was made inert by nitrogen gas purging through the reactor. In addition to this, nitrogen gas flow was allowed to pass continuously during transporting of biomass and sand particles. The flow of nitrogen gas replaces the air from the reactor and permits the pyrolysis reaction under anaerobic condition. Just after the thermal reaction between bio-mass and heat carrier hot sand, the produced gases and vapours escape quickly from the reactor with some char particles and entered into the cyclone chamber wherein char particles are separated from gases and vapours. Gases and vapours are condensed into the condenser which was previously kept in the ice bath. The temperature of the ice bath was maintained at around $-20^{\circ} \mathrm{C}$ the by addition of sodium chloride. The sand-char mixture from the reactor and cyclone chamber and non-condensable gases from the condenser were recycled to the combustor chamber by using air pump. The formation rate of the dark brown colour liquid product was calculated from the direct weighing of the collected liquid after certain time interval. The conversion rate of bio-mass to bio-oil was calculated by the amount of biooil collected for a certain time divided by total feeding of biomass for that time and multiplied by hundred.

\section{Characterization of bio-oil}

The dark brown bio-oil produced from bio-mass by pyrolysis reaction was analyzed as it's density, viscosity, water content, $\mathrm{pH}$, solid content, ash content, acid value Asadullah et al., 2007; Asadullah et al., 2007). The density was measured with a density measurement bottle. Viscosity of the bio-oil is the measure of its internal friction which resists the flow of the fluid. Water content in the bio-oil was measured by KarlFischer titrimetric method. The $\mathrm{pH}$ was measured with a digital pH meter (Hanna Model-HI 8424) The solid content in the pyrolysis oil was measured as ethanol insoluble portion. The lignin portion was measured as water insoluble fraction by using phase separation. The acid value of the bio-oil was determined by direct titration with standard potassium hydroxide solution. Ash content was calculated by burning the bio-oil with supplying excess air in a muffle furnace. 


\section{Results and Discussion}

\section{Physical properties of bio-mass}

The physical properties and chemical composition of feed stock (bio-mass) play an important role in the yield and properties of bio-oil. Therefore, the biomass used as the feed stock for pyrolysis reaction was characterized in order to know the physical properties and chemical composition. The raw bio-mass usually contains about $50 \%$ moisture. For pyrolysis, higher water content in the feed stock has some adverse role such as extra heat is required for vapourising the moisture and heating the vapour to the reactor temperature. However, for the production of bio-oil, the water content in the bio-mass should be typically less than $10 \%$ (Lang et al., 2001) and thus the raw bio-mass was dried in the sunlight. The moisture content of the sun dried biomass normally varies in the range from 3 to $10 \%$. From the thermo gravimetric analysis (Fig. 2) of bio-mass, it can be found that sun dried bio-mass contains about $4 \%$ moisture content. The thickness of the particle has an important role in the surface area per unit weight, the lower the particle size the higher the surface area, which leads to the high heat transfer rate from the outer surface to the center of the particles. For the fluidized bed reactor, the particle size of bio-mass should be less than $2 \mathrm{~mm}$ in size (Lang et al., 2001). Thus, for fast heat transfer, the bio-mass was crushed in a crushing machine and the particle size was maintained within the range of about $0.5-1.0 \mathrm{~mm}$. Properties of bio-mass are given in the following Table II.

Table II. Physical properties of bio-mass

\begin{tabular}{l|c|c}
\hline \multirow{2}{*}{ Properties } & \multicolumn{2}{|c}{ Values } \\
\cline { 2 - 3 } & Jute stick & Bagasse \\
\hline Moisture content (wt $\%)$ & 3.0 & 4.0 \\
Particle size (mm) & $0.5-1.0$ & $0.5-1.0$ \\
Density (dry powder, $\mathrm{Kg} / \mathrm{m}^{3}$ ) & 110.0 & 120.0 \\
Heat value (MJ/kg) & 19.7 & 19.2 \\
Volatile fraction (wt\%) & $76-78$ & $68-70$ \\
Fixed carbon (wt\%) & $21-23$ & $27-29$ \\
Ash content (wt $\%)$ & 0.62 & 1.26 \\
\hline
\end{tabular}

The density of bio-mass is one of the important factors to be considered for the production of bio-oil before pyrolysis. This is because the density is directly related to the energy content in a given volume of bio-mass and it affects the size of plant, the storage area needed and the transportation arrangements. The bulk densities of sun dried bagasse and jute stick were found to be 120 and $110 \mathrm{~kg} / \mathrm{m}^{3}$ respectively. The energy contents in the bagasse and jute stick were calculated 19.2 and $19.7 \mathrm{MJ} / \mathrm{kg}$ respectively. Comparing the density and energy content in the bagasse and jute stick with cedar wood of Japan $\left(70 \mathrm{~kg} / \mathrm{m}^{3}\right.$ and $\left.19.1 \mathrm{MJ} / \mathrm{kg}\right)$, this clearly suggests that the bio-energy plant using bagasse and jute stick will be more efficient than some wood sources available in the world (Asadullah et al., 2004; Srinivasakannan and Bakar, 2004; Daud et al., 2000).

\section{Thermo gravimetric analysis of bio-mass}

The bio-mass was characterized by thermo gravimetric analysis (TGA) method for the investigation of moisture content by percent weight loss with increase in temperature, volatile fraction of bio-mass, the percent of fixed carbon and ash content. TGA experiment was carried out in a Carbolite Round Furnace of Type CFT 12/65/550 heating range from room temperature to $1200^{\circ} \mathrm{C}$. About $1 \mathrm{~g}$ of sample for TGA experiment was used and heated batch wise with $20^{\circ} \mathrm{C}$ interval from room temperature to $1000^{\circ} \mathrm{C}$. Every $20^{\circ} \mathrm{C}$ temperature increase, the sample was kept for about $10 \mathrm{~min}$ in the furnace, cooled in a desicator and then taken the weight. The TGA graphs are shown in the Figure 2.

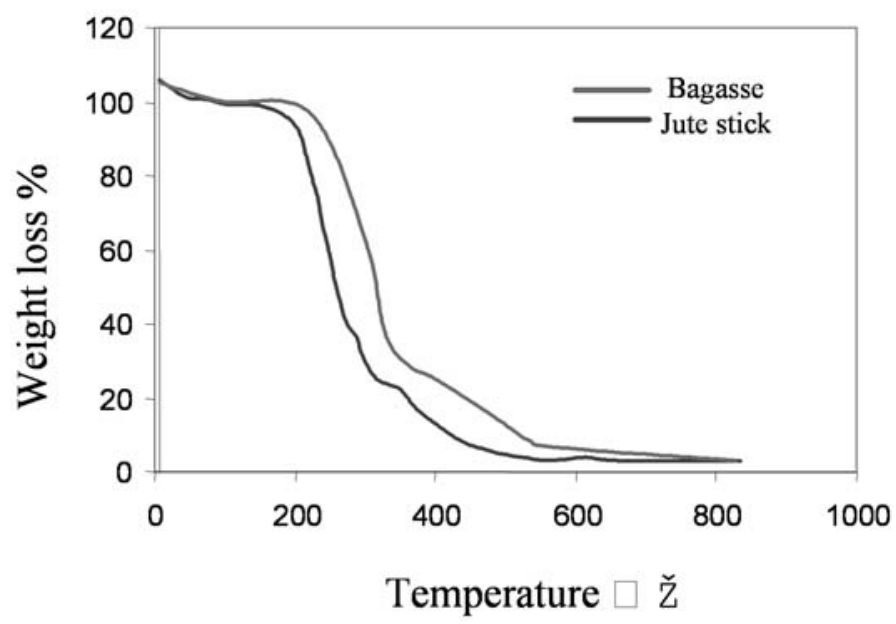

Fig. 2: Thermo gravimetric analysis (TGA) profile of biomasses

According to this TGA graph, the percent of weight loss increases slowly up to $200^{\circ} \mathrm{C}$ and then drastically dropped down in between $200-400^{\circ} \mathrm{C}$ temperature. From the figure, it can be clearly seen that the volatile fractions of bio-mass 
until around $400^{\circ} \mathrm{C}$ was about $70 \mathrm{wt} \%$, the fixed carbon was around $28 \mathrm{wt} \%$ in between $400-600^{\circ} \mathrm{C}$ and the rest $3 \mathrm{wt} \%$ was observed as ash content over $600^{\circ} \mathrm{C}$ even at around $1000^{\circ} \mathrm{C}$. The TGA results show that the volatile content in jute stick was higher than in Bagasee. In addition to this, jute stick contains very small amount of ash in comparison to Bagasse. Therefore, it can be considered that jute stick is a suitable fuel stock feeding for low temperature pyrolysis for the production of bio-oil. From the ultimate analysis (Table I), it has been found that the jute stick contains higher percentage of carbon content than Bagasse. The volatile materials mainly derived from the cellulose and hemicellulose which was likely to be converted to bio-oil in pyrolysis reaction. The carbon which converted to char or other solid carbonaceous materials is called the fixed carbon which mainly derived from lignin contained in the bio-mass. The fixed carbon is not usually vaporized at pyrolysis temperature at around $500^{\circ} \mathrm{C}$. This result reveals that the higher the volatile content the higher the bio-oil yield from the pyrolysis of bio-mass. Proximate and ultimate analyses (Asadulah et al., 2007) reported that bagasse and jute stick contain higher percentages of high volatile fraction in comparison to other agricultural and forestry based bio-mass (Asadullah et $a l ., 2004)$. Another test was carried out for the investigation of fixed carbon after pyrolysis temperature. The solid char was heated again from 500 to $1000^{\circ} \mathrm{C}$ in the furnace under the flow of air passing. A closed conical flask containing lime water was placed on the other end of furnace i.e. at the out let of gas flow. The gas produced was allowed to pass into the lime water which formed white precipitation of calcium carbonate. This experiment revealed that after pyrolysis temperature some fixed carbon decomposes at higher temperature and produces mostly non-condensable gases, which then reacts with lime water to produce white precipitation of calcium carbonate. The non-condensable gases include carbon based compounds such as $\mathrm{CO}, \mathrm{CO}_{2}, \mathrm{CH}_{4}$ and many other gaseous hydrocarbons.

\section{Effect of temperature on the product distribution}

The effect of temperature on the production yields of bio-oil, char and gases (Asadullah et al., 2007) is given in the Figure 3 . To evaluate the effect of temperature on the product distribution, the pyrolysis of bio-mass was performed at different temperatures from 300 to $600^{\circ} \mathrm{C}$. It is reported in the published paper that the fixed carbon can not be decomposed at pyrolysis temperature $\left(500^{\circ} \mathrm{C}\right)$. According to the result, it can be found that the weight percentage of non-condensable gases drasticllay increased and the yields of liquid fuel as well as char gradully decreased after the pyrolysis temperature. But why these happen has not been investiagted and reported in the publication. Based on this result, it was further investigated to understand the states of fixed carbon after pyrolysis temperature. However, at low temperature such as $300^{\circ} \mathrm{C}$, the decomposition of bio-mass starts, bio-oil and gas yields are very low but char yield is very high. As the temperature increased, the bio-oil and and gas yields were increased remarkably and thus the char yield was decreased. The distribution of different compounds mostly depends on the types of bio-mass and on the process severity such as temperature, residence time and heating rate profiles (Bridgwater, 2004). Lower process temperature and longer vapour residence times favour the production of charcoal. High temperature and longer vapour residence time increase the bio-mass conversion to gases. Moderate temperature and short vapour residence time are optimum for producing condensable vapour to liquid.

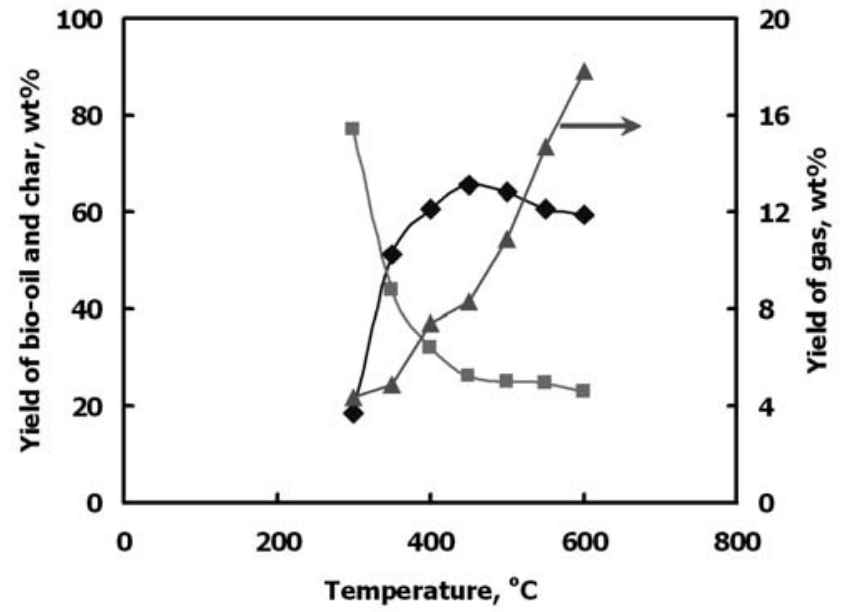

Fig. 3: Effect of temperature on the production yields of bio-oil, char and gases

From the result it can be seen that the char yield decreased suddenly with increasing temperature from about 300 to $450^{\circ} \mathrm{C}$ and then it decreased slowly with increasing temperature. At low temperature the secondary cracking and reforming of bio-mass derived high molecular weight organic molecules is difficult, these temperature dependent reactions usually proceed above $400^{\circ} \mathrm{C}$ (Asadullah et al., 2003; Asdullah et al., 2003; Asdullah et al., 2003; Asdullah et al., 2003). Thus, the char yield in this process was very high at $300^{\circ} \mathrm{C}$ where cracking of high molecular weight compounds could not take place. An increase in pyrolysis severity reduces the organic liquid yield due to cracking of the vapours and formation of gases but leaves the organic liquid with less oxygen. Thus, temperature above $500^{\circ} \mathrm{C}$ reduced the yield of bio-oil and increased the yield of gases. This 
result implies that after pyrolysis temperature, some fixed carbon decompose at higher temperature and produce mostly non-condensable gases a sit was observed in the experiment of TGA. For this reason, after pyrolysis temperature, the production of both the liquid fuel and char decrease whereas yield of gas increased drastically with temperature as it can be seen in the Figure 3.

Table III: Conditions for biomas pyrolysis

\begin{tabular}{l|c}
\hline Conditions & Values \\
\hline Amount of bio-mass $(\mathrm{gm})$ & 200 \\
Temperature $\left({ }^{\circ} \mathrm{C}\right)$ & 500 \\
Temperature increasing rate $(. / \mathrm{min})$ & 50 \\
Nitrogen gas flow rate $(\mathrm{ml} / \mathrm{min})$ & 200 \\
Ice bath temperature $\left({ }^{\circ} \mathrm{C}\right)$ & 200 \\
\hline
\end{tabular}

\section{Prolysis of bio-mass}

In this work the pyrolysis of bagasse and jute stick was performed separately in a fluidized bed laboratory scale circulating reactor. The combustor temperature was increased to desired temperature $\left(400-500^{\circ} \mathrm{C}\right)$ within $10 \mathrm{~min}$ for heating sand then the hot sand was allowed to flow into the reactor.

Table IV: Yields of pyrolysis products in weight percentage cyclone into the combustor. Table IV shows that the yields of bio-oil from both bagasse and jute stick pyrolyses reaction has increased than the previous work.

The fluidization of sand particles enhanced the heat transfer rate to the bio-mass particles so as to increase the bio-oil yield and decrease the char formation. This is because the heat from the hot sand carrier is directly transferred to the object to be pyrolyzed and thus the heat loss is low. The formation rate of bio-oil products was previously low and formation of char products was high than the present bio-oil production. This is because the high molecular weigh bio-oil vapour gradually deposited on the heat carrier so as to decrease the heat transfer rate from the surface of the hot sand to the bio-mass particles to be pyrolysed through the comparatively lower conductive organic coating. On the other hand, the formation rate of char increased in the pyrolysis reaction due to the slower heat transfer rate, which usually facilitates the char formation.

\section{Physical and chemical analysis of bio-oil}

The bio-oil obtained from fluidized bed circulating pyrolysis reactor was also characterized by measuring the density, viscosity, $\mathrm{pH}$, acid value, water content, lignin content, solid char content and ash content. The results of these analyses are given in the Table $\mathrm{V}$.

\begin{tabular}{l|c|c|c|c|c|c|c|c}
\hline \multirow{2}{*}{ Bio-mass } & \multicolumn{3}{|c|}{ Products of previous pyrolysis } & \multicolumn{4}{c}{ Product of present pyrolysis } \\
\cline { 2 - 9 } & Bio-oil & Char & Gas & Total & Bio-oil & Char & Gas & Total \\
\hline Bagasse & 66.13 & 24.86 & 9.01 & 100 & 69.5 & 19.4 & 10.9 & 100 \\
Jute stick & 66.73 & 22.66 & 10.48 & 100 & 68.2 & 21.7 & 9.8 & 100 \\
\hline
\end{tabular}

The bio-mass powder of $0.5-1.0 \mathrm{~mm}$ size was fed continuously along with hot sand in the reactor. The nitrogen gas was passed from the bottom part of the reactor. The pyrolysis reaction started and a thick white smoke produced in the reactor entered into the cyclone and finally it was observed in the ice cold bottle collector. For the production of bio-oil, the bio-mass pyrolysis was performed according to the conditions, which are given in the Table III.

The bio-oil yields including water content at $500^{\circ} \mathrm{C}$ and chars from bagasse and jute stick pyrolyses are given in the Table IV in comparison to the bio-oil yields from the previous work. The carbon containing non-condensable gases were identified (Asadullah et al., 2007) by gas chromatograph (GC) equipped with flame ionization detector (FID). In the present work, the non-condensable gases were recycled from the condenser along with char from reactor and
Table V. Physical properties of bio-oil produced by fluidized bed circulating pyrolysis reactor

\begin{tabular}{l|c|c}
\hline \multirow{2}{*}{ Properties } & \multicolumn{2}{|c}{ Values } \\
\cline { 2 - 3 } & Jute stick & Bagasse \\
\hline Density at $20{ }^{\circ} \mathrm{C}(\mathrm{gm} / \mathrm{cc})$ & 1.05 & 1.1 \\
Viscosity at $20^{\circ} \mathrm{C}$ (centipoises) & 2.32 & 3.1 \\
$\mathrm{pH}$ & 4.0 & 4.1 \\
$\mathrm{Water}$ content $(\mathrm{wt} \%)$ & 13.8 & 14 \\
Char/ solid content $(\mathrm{wt} \%)$ & 0.04 & 0.05 \\
Lignin content $(\mathrm{wt} \%)$ & 3.7 & 2.5 \\
Acid value $(\mathrm{mgKOH} / \mathrm{gm})$ & 134 & 126.3 \\
Ash content $(\mathrm{wt} \%)$ & 0.02 & 0.03 \\
\hline
\end{tabular}

Pyrolytic bio-oil consists of water content and organic compounds that are condensed and collected after the pyrolysis 
reaction, usually after the removal of char from the hot gas and vapour stream. This liquid is very complex mixture that contains molecular fragments of the cellulose, hemicellulose and lignin polymers that are able to escape the pyrolysis environment by volatilizing or by being part of a liquid droplet small enough to be entrained from the reactor (Lede et al., 1999). Extensive reviews on the chemical (Milne et al., 1996) and physical properties of pyrolysis oils have recently been published (Osama and Meier, 2002). In our previous work (Asadullah et al., 2007) the bio-oils produced from bagasse and jute stick through pyrolysis reaction were characterized.

\section{Conclusion}

The pyrolysis of bagasse and jute stick was performed at $500^{\circ} \mathrm{C}$ in a circulating fluidized bed reactor to produce biooil more efficiently. The yields of bio-oil from both biomasses increased and yields of char formation were decreased than former investigation. Sand heating insight the combustor and its heat transfer rate to the bio-mass through the circulating system and the recycling of sand and char to the combustor provided the pyrolysis efficiency of the fluidized bed reactor for the production of bio-oil.

\section{Acknowledgement}

The authors thank the Department of Applied Chemistry and Chemical Engineering for kind cooperation and financial support to proceed with this challenging research activities.

\section{References}

Andrews R. G. and Patniak P. C. (1996). Feasibility of utilizing a biomass derived fuel for industrial gas turbine applications. Bio-oil production and utilization. Proceedings of the 2nd EU/Canada workshop on thermal biomass processing. Newbury: CPL Press; $p$ 236-45.

Asadullah M., Miyazawa T., Ito S. I., Kunimori K., Koyama S. and Tomishige K. (2004). A comparison of $\mathrm{Rh} / \mathrm{CeO}_{2} / \mathrm{SiO}_{2}$ catalysts with steam reforming catalysts, dolomite and inert materials as bed materials in low throughput fluidized bed gasification systems. Biomass Bioenergy; 26: 269-79.

Asadullah M., Rahman M. A., Ali M. M., Rahman M. S., Motin M. A., Sultan M. B. and Alam M. R. (2007). Fuel 86: 2514-2520.

Asadullah M., Miyazawa T., Ito S. I., Kunimori K., Yamada M. and Tomishige K. (2004). Gasification of different biomasses in a dual bed gasifier system combined with novel catalysts with high energy efficiency, Appl. Catal. A: Gen; 267: 95-102.

Asadullah M., Miyazawa T., Ito S. I., Kunimori K., Yamada M. and Tomishige K. (2003). Demonstration of real bio-mass gasification drastically promoted by effective catalyst. App Catal A: Gen; 246: 10316.

Asadullah M., Miyazawa T., Ito S. I., Kunimori K., Yamada M. and Tomishige K. (2003). Catalyst development for the gasification of biomass in the dual-bed gasifier. App Catal A: Gen: 255: 169-80.

Asadullah M., Miyazawa T., Ito S. I., Kunimori K., Yamada M. and Tomishige K. (2003). Catalyst performance in reforming of tar derived from biomass over noble metal catalyst. Green Chem, 5: 399-403.

Asadullah M., Miyazawa T., Ito S. I., Kunimori K., Yamada M. and Tomishige K. (2003). Catalyst development for low temperature gasification of biomass: function of char removal in fluidized bed reactor. Stud Surf Sci Catal, 145: 307-10.

Asadullah M., Rahman M. A., Ali M. M., Rahman M. S., Motin M. A., Sultan M. B. and Alam M. R., (2007) Fuel 86, 2514-2520; M. Asadullah et al. (2007) Bio Resource Technology 1-7.

Bangladesh (2004). Sector-Wise Final Consumption of Commercial Energy, Statistical Year Book of Bangladesh, Planning division, Ministry of Planning, Government of People's Republic of Bangladesh; p 233-7.

Bionett. (1998-2000). Norsk Bioenergi Nettverk Sluttrapport Temablad 8.

Boateng A. A., Mullen C. A., Neil M. G., Kevin B. H., Thomas E. D., Isabel M. L. and James E. M. (2010). Sustainable production of bioenergy and biochar from the straw of high biomass soybean lines via fast pyrolysis. Environmental Progress \& Sustaiable Energy, AlChE, 28(3): 1-9.

Bridgwater A. V. (1966). Productions of High-Grade Fuels and Chemicals from Catalytic of Biomass. Catalysis Today, 29: 285.

Bridgwater A. V. (1991). Cottam, M-L Costs and Opportunities for Biomass Pyrolysis Liquids Production and Upgrading, Proceedings, 6th Conference on Biomass for Energy, Industry and the Environment, Athens. 
Bridgwater A. V. (1994). Catalysis in Thermal Biomass Conversion. Applied Catalysis A: 116: 5.

Bridgwater A. V. and Peacocke G. V. C. (1999). Fast Pyrolysis Processes for Biomass, Sustainable and Renewable Energy Reviews, 4: 1-73.

Bridgwater A. V., Czemik S. and Piskorz J. (2001). An Overview of Fast Pyrolysis Technology, In: Progress in Thermochemical Biomass Conversion (Ed. A.V. Bridgwater), Blackwell, Oxford, UK, p 977-997.

Bridgwater A. V. (2003). Renewable fuels and Chemicals by thermal processing of biomass. Chemical Engineering Journal. 91: 81.

Bridgwater A. V. and Maniatis K. (2004). The production of Biofuels by the Thermochemical Processing of Biomass, In: Molecular to Global Photosynthesis (Eds. M.D. Archer, J. Barber), IC Press, London, UK, p 521-612.

Bridgewater A.V. (2004) Review Paper, UDC: 662.73/75, Thermal Science, 8(2): 21-49.

Brown D.B. (1996). Continuous ablative regenerator system, bio-oil production and utilization. In: A.V. Bridgwater, E.N. Hogan, editors. Proceedings of the 2nd EUCanada workshop of thermal bio-mass processing. Berkshire: CPL Press; p 96-101.

Brown R C. and Wright M. M. (2008). Distributed processing of bio-mass to bio-oil for subsequent production of Fischer-Tropsch liquids. Biofuels Bioprod. Bioref 2(3): 229.

Choi H. S., Choi S. C. and Kim S. J. (2009) Numerical Study of Fast Pyrolysis of Woody Biomass in a GravityDriven Reactor. Environmental Progress \& Sustaiable Energy, AlChE, 28(3): 418.

Czernik S., Schahill J., and Diebold J. (1995). The Production of Liquid Fuel by Fast Pyrolysis of Biomass. J. Sol. Energy Eng. 117: 2.

Diebold J. and Scahill J. (1988). Production of Primary Pyrolysis Oils in a Vortex Reactor, in: Pyrolysis Oils from Biomass:Producing, Analyzing and Upgrading. ACS Symposium Series 376: 31.

Elliott D. C. and Baker E. (1983). Hydrotreating Biomass Liquids to Produce Hydrocarbon Fuels, Proceedings, Energy from Biomass and Wastes. Orlando, FL. USA, IGT ChicagoIL. USA, p 765.

Elliott D. C., Todd R. H., Gary G. N., Leslie J. R. and Alan
H. Z. (2009). Catalytic Hydroprocessing of Biomass Fast Pyrolysis Bio-oil to Produce Hydrocarbon Products. Environmental Progress \& Sustaiable Energy, AlChE, 28(3): 441.

Fagernas L. (1995). Chemical and physical characterization of bio-mass based pyrolysis oils. Literature review, Technical research center of Finland, Espoo. VTT Research Note 1706.

Fao, (2006) www.fao.org/docrep/x5328E/x5328e08.htm

Graham R. G., Freel B. A. and Bergougnou M. A. (1988). The production of pyrolysis liquids, Gas and Char from Wood and Cellulose by Fast Pyrolysis. in: Research in Thermochemical Biomass Conversion. Elsevier, London, p629.

Gust S., Nieminen J. P., Nyronen T. and Forestera T. M. (2003). Liquified Wood Fuel Pilot Plant, in: Pyrolysis and Gasification of Biomass and Wastes. CPL Press, Newbury, UK, p 169.

Houghton J. T., Ding Y., Griggs D. J., Noguer M., van der Linden P. J. and Dai X. (2001). Intergovernmental panel on climate change. Climate change Cambridge: Cambridge University Press.

IEA Bioenergy, (1998). The Role of Bioenergy in Greeenhouse Gas Migration, Position Paper, IEA Bioenergy, New Zealand.

Islam M. R., Nabi M. N. and Islam M. N. (2003). Department of Mechanical Engineering BIT, Rajshahi, 38: 38 .

Khodier A., Paul K., Nigel L., Nigel S., John O. and Tony B. (2009). Pilot-Scale Combustion of Fast-Pyrolysis BioOil: Ash deposition and Gaseous Emissions. Environmental Progress \& Sustainable Enrgy, AlChE, 28(3): 97.

Laird A. D., Brown C. R., Amonette J. E. and Lehmann J. (2009). Review of the pyrolysis platform for coproducing bio-oil and biochar. Biofpr, 3(5): 547.

Lang X., Dalai A. K., Bakshi N. N., Reaney M. J. and Hertz P. B. (2001). Preparation and characterization of biodiesel from various bio-oils, Bioresource Technology, 80: $53-62$.

Leech J. (1997). Running a dual fuel diesel engine on crude pyrolysis oil. In: M. Kaltschmitt, A.V. Bridgwater, editors. Biomass gasification and pyrolysis, state of the art and future prospects. Berkshire: CPL press; 495-7. 
Lede J., Diebold J. P., Peacocke G. V. V. and Piskorz J. (1999). The nature and properties of intermediate unvaporized biomass pyrolysis materials. In: A.V. Bridgwater, S. Czernik, J. Diebold, D. Meier, A. Osama, C. Picocke, J. Piskorz, and Radlein D. (Eds.) Fast pyrolysis of biomass: A Hand Book. CPL Scientific publishing service ltd. Newbury, p 51-56.

Mia M. Y. and Banik S. K. (2008). Bio-oil from City Garbage, BCSIR science Laboratory, Daily Prothom Alo.

Milne T. A., Agblevor F. A., Davis M., Deutch S. and Johnson D. (1996). A review of the chemical composition of fast pyrolysis oils from biomass. In: A.V. Bridgwater, S. Czernik, J. Diebold, D. Meier, A. Osama, C. Picocke, J. Piskorz, D. Radlein (Eds.) Fast pyrolysis of biomass: A Hand Book. CPL Scientific publishing services ltd. Newbury p 70-75.

McNelis B., van Roekel G.and Preiser K. (2002). Renewable energy technology for developing countries, the future for renewable energy: prospects and directions, EUREC Agency, London; European Commission, Communication from the Commission: Energy for the Future: Renewable Energy SourcesWhite Paper for a Community Strategy and Action Plan, COM [97] 599, Brussels.

McGowan F. (2000). Controlling the greenhouse effect: the role of renewables. Energy Policy 1991; 19:111-8. International Energy Agency, World Energy Outlook 2000, IEA, Paris.

Osama A. and Meier D. (2002). Analysis, characterization and test methods of fast pyrolysis liquids. In: A.V. Bridgwater (Ed.), In: Fast pyrolysis of biomass: A Hand Book, vol. 2 CPL Press, Newbury, Berkshire, p 23-40.

Osama A., Elliott D. C. And Muller S. (2009). Quality Control in Fast Pyrolysis Bio-Oil Production and Use. Environmental Progress \& Sustaiable Energy, AlChE, 28(3): 404.

Park H. J., Heo H. S., Yim J. H., Jeon J. K., Ko Y. S., Kim S. S. and Park Y. K. (2010). Catalytic pyrolysis of Japanese larch using spent HZSM-5. Korean J. Chem. Eng. 27: 73.

Peacocke G. V. C. and Bridgwater A. V. (1996). Ablative Fast Pyrolysis of Biomass for Liquids: Results and Analyses, in: Bio-Oil Production and Utilization, CPL Press, Newbury UK, p 35.
Putra Z. A., Magalhaes A. I. P., Dragana P., Alex L. R., and Geert T. (2009). Techno-economic assessment of biomass preconversion processes as a part of biomass-to liquids line-up. Biofpr, 3(6): 584.

Ragavendra P., Balegedde R., Guss V. R., Wim P. M. V. S. and Sascha R. A. K. (2009). Evaporation of Biomass Fast Pyrolysis Oil: Evaluation of Char Formation. Environmental Progress \& Sustainable Energy AlChE, 28(3): 410 .

Robson A. (2001). 25 tpd Border Biofuels/Dyna Motive Plant in the UK, PyNe Newsletter, 11 Aston University Birmingham UK, p 1.

Scott D. S., Piskorz J. Radlein D. (1985) Liquid Product from the Continuous Flash Pyrolysis of Biomass. Ind. Eng. Chem. Process Des. Dev. 24: 581.

Secowarwick, (2006). www.secowarwick.com/thermal/bulleting/rotaryretort.htm

Selhan K. (1009). Energy production from the pyrolysis of waste biomasses. Int. J Energy Res. 33: 576.

Venderbosch R. H. and Prins W. (2010). Fast Pyrolysis Technology Development. Biofuel Bioproducts and Biorefing (Biofpr), 4 (2): 178.

Wagennar B. M., Vanderbosch R. H., Carrasco J., Strenziok R. and van der A. B. (2000, 2001). Scaling up of the rotating cone technology for biomass fast pyrolysis, proceedings, 1st world conference and exhibition on biomass for energy and industry, Seville, Spain, UK, p 1514.

Williams P. T. and Horne P. A. (1994). Characterization of Oilsfrom the Fluidized Bed Pyrolysis of Biomass with Zeolite Catalyst Upgrading, Biomass and Bioenergy 7: 223.

Wright M. M., Brown R. C. and Boateng A. A. (2008) Distributed processing of bio-mass to bio-oil for subsequent production of Fischer-Tropsch liquids. Biofpr, 2(3): 229.

Xiao R., Zhang H., Pan Q., Song Q., and He H. (2009) Hydrodynamics of a Novel Biomass Autothermal Fast Pyrolysis Reactor: Flow Pattern and Pressure Drop. Chem. Eng. Technol. 32(1): 27.

XiFeng Z. H. U., Qiang L. U., WenZhi L. I., Ying Z. and Chen D. (2009). On-line catalytic upgrading of biomass fast pyrolysis products. Chinese Science Bulletin 54, p 1941.

Received :March 11, 2010;

Accepted : December 14, 2010 